\title{
Pancreatic polypeptide and other hormones in pancreas of obese $(\mathrm{ob} / \mathrm{ob})$ mice
}

\author{
T. Tomita, V. Doull, J. R. Kimmel and H. G. Pollock \\ Departments of Pathology and Biochemistry, University of Kansas College of Health Sciences and Hospital, Kansas City, Kansas, USA
}

\begin{abstract}
Summary. The insulin, glucagon, somatostatin and pancreatic polypeptide content of acid-ethanol extracts of pancreas from lean and obese (ob/ob) mice of various ages was determined by radioimmunoassay. Rat and mouse pancreatic polypeptide react weakly with antibodies to avian, bovine and canine pancreatic polypeptide, but immunoassay for this peptide was possible using an antibody to the carboxyl-terminal hexapeptide of bovine pancreatic polypeptide and amino-terminal labelled bovine pancreatic polypeptide as tracer. The insulin, glucagon and pancreatic polypeptide content of pancreas from obese mice was greater than that of lean controls. The in-
\end{abstract}

crease in insulin content uniformly involved ventral, dorsal and splenic lobes. Glucagon content was elevated primarily in the splenic lobe. Pancreatic polypeptide content was most significantly elevated in the splenic lobe where pancreatic polypeptide cells are infrequent in normal lean mice and this was accompanied by increased numbers of pancreatic polypeptide cells per islet in this lobe.

Key words: Pancreatic polypeptide, pancreas, obese mice, insulin, glucagon, somatostatin.
The characteristics of the endocrine pancreas in several strains of congenitally obese mice have been studied extensively [1]. In the ob/ob strain, such studies have shown an increase in islet cell mass resulting primarily from hypertrophy and hyperplasia of $\beta$ cells [1-4] and associated with increased pancreatic insulin content [5-7]. There is also a significant, but less marked, increase in pancreatic glucagon content in adult $\mathrm{ob} / \mathrm{ob}$ mice [4]. The situation with regard to somatostatin is less clear. There are two reports of decreased somatostatin concentration in islets from ob/ob mice compared with lean controls [8, 9]. Makino et al. [10] found the somatostatin content of tissue from obese and lean animals to be similar. However, Dolais-Kitabgi et al. [11] found the somatostatin content to be significantly increased. These authors also reported increased insulin and glucagon content in obese mice.

Several reports have now appeared which indicate that pancreatic polypeptide (PP) also may be involved in the ob/ob syndrome. Malaisse-Lagae et al. $[12,13]$ observed a decreased relative abundance of PP and somatostatin cells in the islets of ob/ob mice. They treated these mice with twice daily injections of bovine PP for 12 days and observed arrested weight gain compared with saline-injected obese mice. There was also a modest decrease in food intake [13]. The potential in- volvement of an islet factor in the ob/ob syndrome was demonstrated by Strautz [14], when he studied the implantation of islets from lean mice into obese animals. Gates et al. $[15,16]$ studied New Zealand obese (NZO) mice using the same implantation technique and observed that the implanted islets corrected the hyperglycaemia and hyperinsulinaemia and slowed weight gain. They demonstrated further that injections of either avian or bovine $\mathrm{PP}$, but not somatostatin or other peptides, produced the same effect as islet implantation [17]. Using an immunoassay based on antibody to human PP, they estimated that the NZO animals had PP plasma levels much lower than lean controls. Gingerich et al. [18] reported an increase in the number of PP cells in islets from ob/ob mice as well as increased PP content of the pancreas. Finally, Mordes et al. [19] gave ob/ $o b$ mice and lean littermates continuous infusions of bovine PP, using miniature osmotic pumps, and found that the obese animals lost weight and developed diarrhoea. Lean controls were not affected by the same treatment.

These results suggest an abnormality in PP secretion and indeed several clinical studies have reported reduced PP secretion in obese subjects in response to a physiological stimulus $[20,21]$. This change is especially striking in children with Prader-Willi syndrome [22]. 
Extension of studies in obese mice has been hampered by the lack of a sensitive immunoassay since none of the usual antibodies to avian or mammalian PP reacts well with extracts of mouse or rat pancreas. The purpose of this study was to develop a radioimmunoassay for rat and mouse PP, using antibody raised to the carboxyl-terminal hexapeptide of bovine PP, and to apply this immunoassay to extracts of pancreas from ob/ ob mice and lean littermates. The pancreatic content of insulin, glucagon and somatostatin was estimated also.

\section{Materials and methods}

Bovine PP and rabbit anti-serum to human and bovine PP (615-R110-146-16) were generously supplied by Dr. R. E. Chance, Eli Lilly, Indianapolis, Indiana, USA. Canine PP was prepared in our laboratory as described previously [23]. Antiserum to avian PP and canine PP were raised in rabbits. Rabbit antiserum to the carboxyl-terminal hexapeptide of bovine PP (PP-221-5) and rabbit anti-glucagon serum (YY 57) were generously donated by Dr. M.O'Hare and Professor K. Buchanan, Institute of Clinical Science, Belfast, Northern Ireland. Goat anti-rabbit IgG and anti-guinea pig IgG were purchased from Antibodies Inc., Davis, California, USA.

Somatostatin, bombesin, substance $\mathrm{P}$, and caerulein were purchased from Sigma Chemicals, St. Louis, Missouri. ${ }^{125}$ I-insulin, ${ }^{125}$ ITyr-1-somatostatin and ${ }^{125} \mathrm{I}$-glucagon were purchased from New England Nuclear, Boston, Massachusetts, USA.

Obese hyperglycaemic mice (ob/ob on the $\mathrm{C} 57 / 6 \mathrm{~J}$ strain) were obtained from Jackson Laboratories, Bar Harbor, Maine and from our own colony established from that strain. Obese animals (ob/ob) were identified by measurement of: (1) body weight, (2) fasting serum glucose level and (3) fasting serum insulin concentration. For the latter determinations, the animals were fasted $4-5 \mathrm{~h}$ and blood was collected from the orbital sinus. In 1-month-old mice, body weight was not reliable in identifying obese animals, but elevation of serum glucose and insulin levels were significant, even at this early age and provided a basis for early selection of obese animals. Lean littermates $(+/$ ?) were used as controls. Comparative data on body weight and serum glucose levels in both groups are shown in Figure 1.

For study of the pancreas, animals were fasted $4-5 \mathrm{~h}$ and then sacrificed under methoxyfluorene anaesthesia. The entire pancreas, with attached spleen, stomach and duodenum, was removed as a unit and then the pancreas was divided into ventral, dorsal, and splenic segments using criteria given by Baetens et al. [24]. After careful removal of adipose tissue, the individual segments were weighed and the peptide hormones were extracted with acid ethanol [23].

Radioimmunoassays for insulin, glucagon, somatostatin and pancreatic polypeptide were performed on several dilutions of the pancreatic acid alcohol extracts to ascertain that data were not derived from extremes of the standard curves. The insulin assay utilized a modification of the double-antibody procedure of Morgan and Lazarow [25]. A previously reported immunoassay was used to estimate glucagon [26]. Immunoassay for somatostatin used the procedure of Lindall [27]. Minimum detectable dose in this assay was approximately $8 \mathrm{pg} /$ tube and $50 \%$ displacement of tracer occurred at $30 \mathrm{pg} /$ tube.

The composition of the buffers used in the assays was: Buffer A: $0.04 \mathrm{~mol} / 1$ monosodium phosphate containing $0.25 \mathrm{~g}$ thiomerasol and $1 \mathrm{~g}$ bovine serum albumin/litre. Buffer $B$ : buffer A containing $9 \mathrm{~g}$ $\mathrm{NaCl} /$ litre; Buffer $C$ : buffer A containing $0.03 \mathrm{~mol} / 1$ EDTA. All buffers were adjusted to $\mathrm{pH}$ 7.4.

Iodination of bovine PP and/or canine PP was performed by an oxidative method described earlier [28] or with the Bolton-Hunter reagent [29]. The immunoassay for murine PP was set up in $12 \times 75 \mathrm{~mm}$ tubes using: (1) $300 \mu \mathrm{l}$ of a 1:4000 dilution of bovine PP-hexapeptide antiserum (PP-221-5) in buffer A; (2) $300 \mu \mathrm{l}$ of canine PP standard or unknown in buffer B; (3) $200 \mu \mathrm{l}$ of buffer A containing $48 \mathrm{pg}$ of Bolton-Hunter labelled bovine PP (initial sp. act. $100-200 \mu \mathrm{Ci} / \mu \mathrm{g}$ ). This
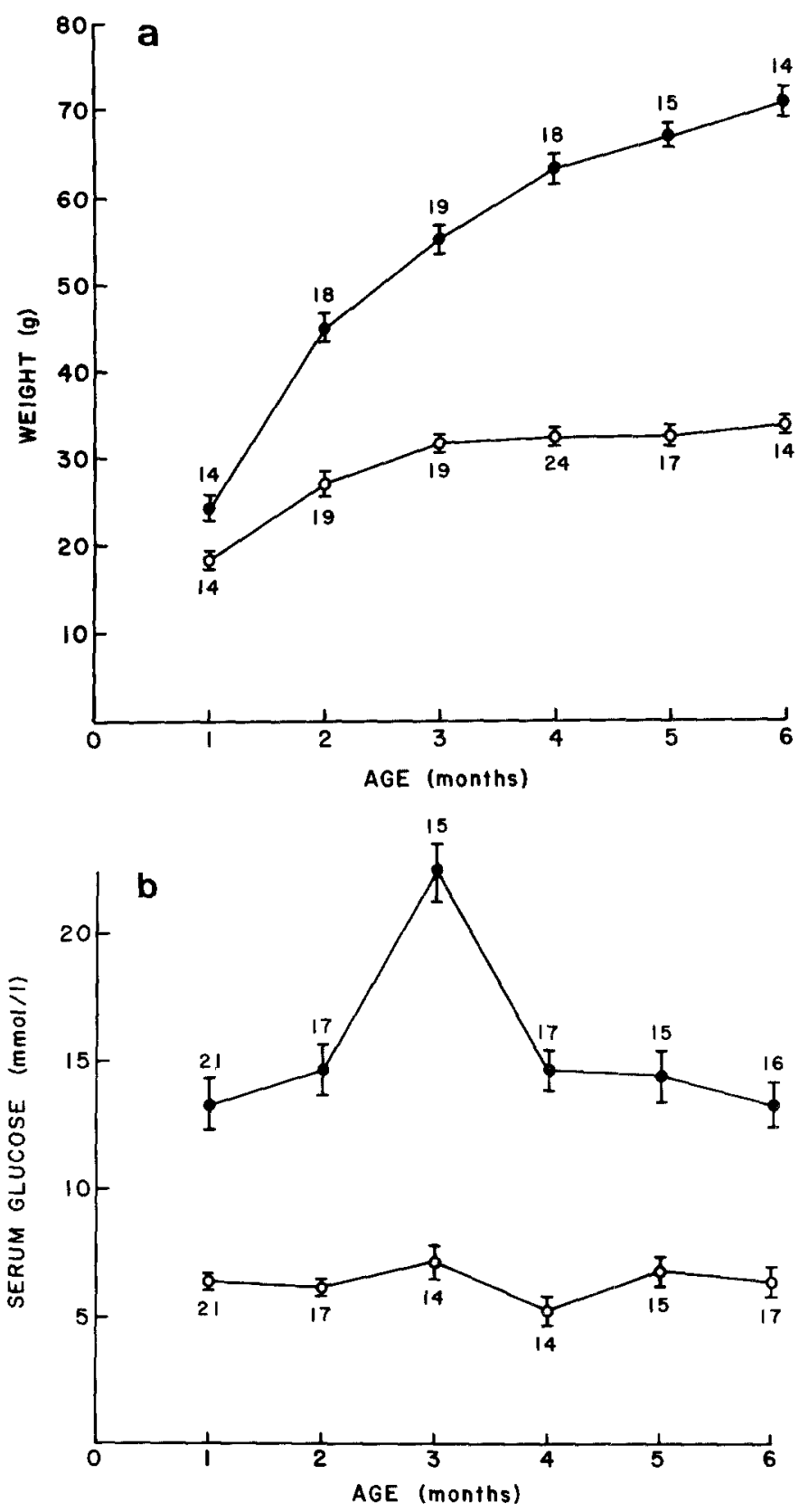

Fig. 1. Comparison of body weight and serum glucose concentration in lean and ob/ob mice as a function of age. Data plotted are mean \pm SEM and show the relevant numbers of mice studied. $O-O$ lean controls, - ob/ob. a Body weight as a function of age; $\mathbf{b}$ serum glucose concentrations in the same animals at various ages

mixture was incubated at $4^{\circ} \mathrm{C}$ for $72 \mathrm{~h}$ after which $200 \mu \mathrm{l}$ of a $1: 100$ dilution of normal rabbit serum in buffer $A$ and $200 \mu 1$ of goat anti-rabbit serum (dilution 1:20-1:40) in buffer $C$ were added. After an additional 24-h incubation, the tubes were centrifuged and the supernatant solutions aspirated. The precipitates were then counted. The data were analyzed as described for avian PP [28].

\section{Results}

\section{Immunoassay for murine $P P$}

A number of antibodies were evaluated for their ability to react with rat or murine PP by observing displace- 
Table 1. Binding of ${ }^{125} \mathrm{I}$-bovine PP by antiserum to the carboxyl-terminal hexapeptide of bovine PP

\begin{tabular}{lll}
\hline $\begin{array}{l}\text { Antiserum } \\
\text { (final dilution) }\end{array}$ & \multicolumn{2}{l}{${ }^{125}$ I-bound (\%) } \\
\cline { 2 - 3 } & $\begin{array}{l}\text { Amino- } \\
\text {-labelled }\end{array}$ & $\begin{array}{l}\text { Carboxyl- } \\
\text { labelled }\end{array}$ \\
\hline $1: 2000$ & - & 27.0 \\
$1: 4000$ & 78.7 & 18.4 \\
$1: 8000$ & 70.1 & 13.3 \\
$1: 16000$ & 57.2 & 9.1 \\
\hline Non-specific binding & 1.9 & 1.5 \\
\hline
\end{tabular}

ment of ${ }^{125}$ I-bovine or canine PP in serial dilutions of an extract of rat or mouse pancreas. The results for rabbit anti-human PP and anti-bovine PP are shown in Figure 2. It is evident that cross-reaction in each case was poor. The reaction with anti-canine PP was similar to that of anti-bovine PP.

Evaluation of antiserum to the carboxyl-terminal hexapeptide involved some modifications of the method, namely a change in the type of ${ }^{125}$ I-PP used as tracer. Oxidative iodination of PP predominantly labels the carboxyl-terminal tyrosinamide [28]; such an iodinated derivative was not bound well by the carboxyl-specific antibody (Table 1). On the other hand, when PP was iodinated with the Bolton-Hunter reagent at the amino terminus, binding was much improved. With ${ }^{125} \mathrm{I}$-bovine PP labelled at the amino terminus, and carboxylspecific anti-hexapeptide serum, the dilution curves for rat, normal and obese mouse pancreatic extracts essentially parallel the standard curve for canine PP (Figs. 2 and 3). Because of this greatly improved sensitivity, it was possible to develop a radioimmunoassay for application to extracts of mouse pancreas.

\section{Characteristics of the immunoassay}

At a final dilution of $1: 16,000$, anti-hexapeptide serum bound approximately $50 \%$ of $48 \mathrm{pg}$ of animo-terminallabelled bovine PP. The standard curve developed with canine PP is shown in Figure 4. Fifty percent displacement of tracer occurred at levels of approximately 0.32 ng canine $\mathrm{PP} /$ tube. The mean minimum detectable level in 14 consecutive assays was $0.008 \mathrm{ng} /$ tube. Within assay variance at the $95 \%$ confidence level was $5.8-7.4 \%$ and between assay variance was $6.0-8.0 \%$ at the same level of confidence. With bovine PP as standard, a similar but less sensitive assay was possible (minimum detectable dose $0.055 \mathrm{ng} /$ tube, 50\% displacement at $0.67 \mathrm{ng} / \mathrm{tube}$, Fig. 4).

The specificity of the antiserum was studied by estimating the ability of various hormones and peptides to compete with the tracer (Table 2). Only avian PP and glucagon showed any measurable ability to displace ${ }^{125} \mathrm{I}$ - canine $\mathrm{PP}$, but the amounts required were so large that neither was considered likely to interfere in the assay. It is possible also that the glucagon used contained a minute amount of PP.

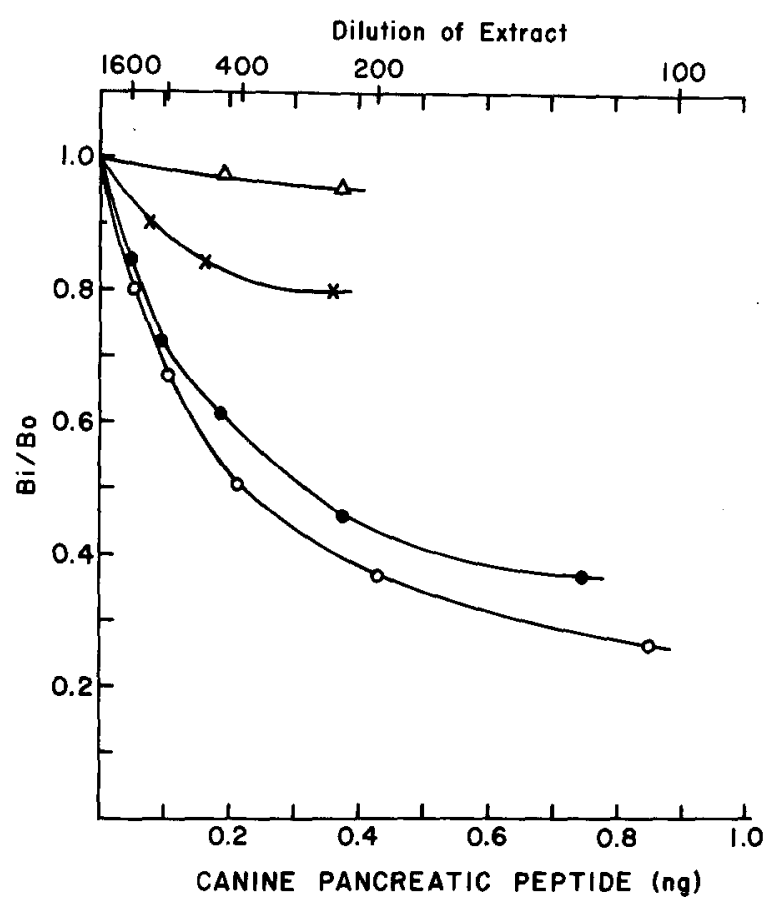

Fig. 2. Reaction of various antisera with serial dilutions of a rat pancreatic extract. The tracer was bovine PP labelled at the amino terminus. (O) Canine PP standard; (O) rat pancreatic extract and antihexapeptide serum; $(\mathrm{X})$ rat pancreatic extract and antiserum to human PP; $(\Delta)$ rat pancreatic extract and anti-serum to bovine PP. $\mathrm{Bi} / \mathrm{Bo}={ }^{125} \mathrm{I}-\mathrm{PP}$ bound at dose $\mathrm{i} / 125 \mathrm{I}-\mathrm{PP}$ bound at dose 0

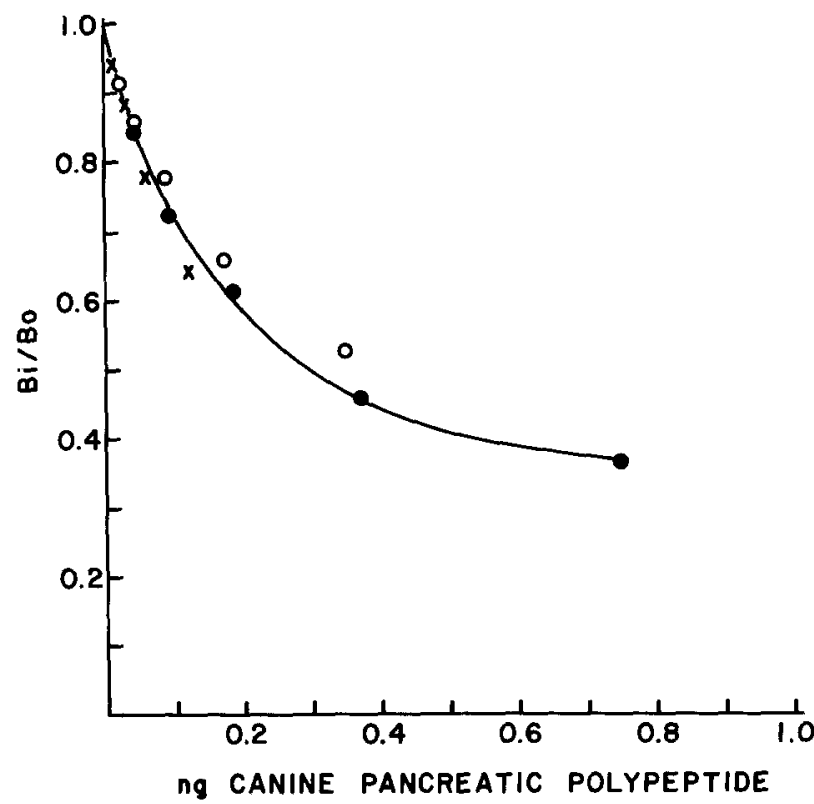

Fig.3. Dilution curve of murine pancreatic extracts generated with anti-hexapeptide serum. (O) Canine PP standard; (O) extracts from pancreas of lean mice; $(X)$ extracts from pancreas of obese mice. The data represent results with doubling dilutions beginning at 1:100. The greatest dilution with a value of $\mathrm{Bi} / \mathrm{B}$ o significantly different from 1 was used to calculate the PP content 


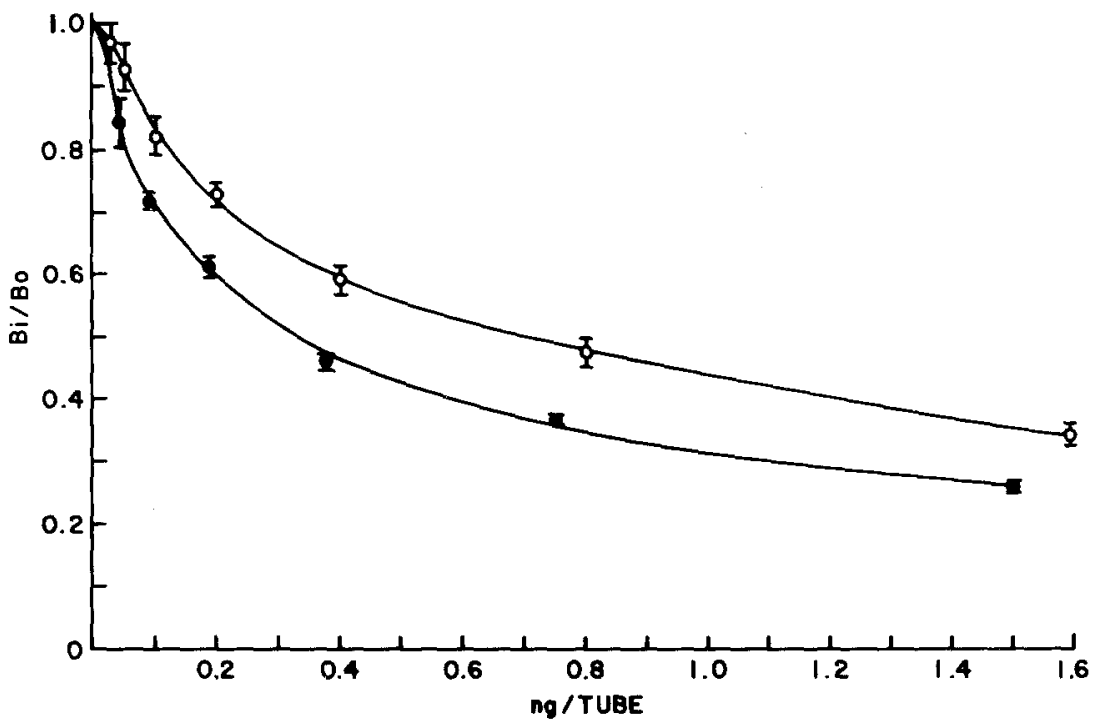

Fig.4. Comparison of immunoassay standard curves generated with anti-hexapeptide serum, aminoterminal labelled bovine $\mathrm{PP}$ and either canine $(-)$ or bovine PP $(O)$ standards. Values plotted are mean \pm SEM

Table 2. Specificity of anti-bovine $\mathrm{PP}_{31-36}$

\begin{tabular}{|c|c|c|c|c|c|c|c|}
\hline $\begin{array}{l}\text { Peptide } \\
\text { level } \\
\text { (ng/tube) }\end{array}$ & \multicolumn{7}{|c|}{ ng bovine equivalents/tube } \\
\hline 125 & 0.04 & 0.09 & - & - & - & - & - \\
\hline 250 & 0.10 & 0.20 & - & - & - & - & - \\
\hline 500 & 0.14 & 0.22 & - & - & 0.01 & - & 0.03 \\
\hline 1000 & 0.31 & 0.34 & 0.02 & - & 0.01 & - & 0.02 \\
\hline
\end{tabular}

\section{Hormone content of mouse pancreatic extracts}

The insulin, glucagon, somatostatin, and PP contents of pancreas from lean and ob/ob mice were determined in extracts of dorsal, ventral and splenic lobes because of the known regional distribution of glucagon and PP [24]. Total pancreatic hormone content was calculated by summation of the content of the individual lobes (Fig. 5).

The well-known increase in insulin content in the pancreas of older ob/ob mice was apparent as well as the lack of change in lean controls. Glucagon content was also higher in the ob/ob animals, but the increase was only two- to threefold compared with fourfold in the case of insulin. At all ages, the PP content of extracts from $\mathrm{ob} / \mathrm{ob}$ pancreas was significantly higher at a level approximately twice that of controls. Both lean and ob/ ob mouse pancreas appear to have the same somatostatin content.

The data for hormone content of the three pancreatic lobes exhibited some interesting features (Fig. 6). Firstly, the four- to fivefold increase in insulin content of pancreas from ob/ob mice uniformly involved the entire pancreas. Secondly, the increase in glucagon content involved primarily the splenic and dorsal lobes, e.g., the lobes which normally contain most A cells. Except for the extracts from 5-month-old mice, there was little increase in glucagon content in the ventral lobe. Thirdly, while PP content was highest in the ventral lobe (the lobe where PP cells normally predominate), the increase in PP content in the ob/ob pancreas, compared with controls, was apparent throughout the pancreas and in the splenic lobe was four to five times that of lean controls, especially in older animals. This finding suggests that, in addition to PP cell hypertrophy in the ventral lobe, there is actual PP cell hyperplasia in a segment of the pancreas where PP cells are scarce in normal mice.

The somatostatin content was not significantly different in the three lobes and, therefore, is not shown in Figure 6.

\section{Discussion}

The radioimmunoassay described in this study has the specificity and precision to permit measurement of PP in pancreatic extracts. However, the assay is not sensitive enough to allow PP determinations in the small amounts of plasma available from mice. Furthermore, the success of the assay was dependent on the method of iodination of tracer bovine PP, and it was necessary to iodinate at the amino terminus with the Bolton-Hun- 


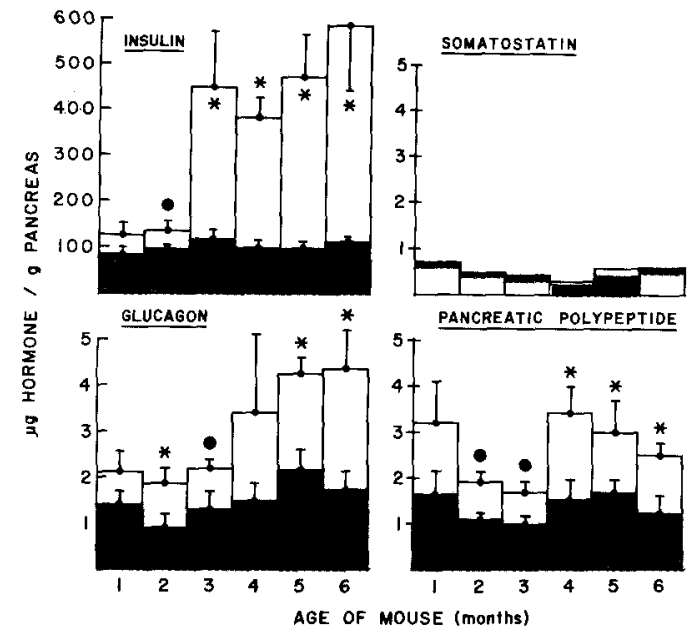

Fig. 5. Hormone content of mouse pancreas. Each peptide hormone was determined by radioimmunoassay in acid-ethanol extracts of mouse pancreas. The data shown are mean \pm SEM and represent the sum of values obtained for individual lobes from four to six mice. Control mice ( $\square$ ), ob/ob ( $\square)$; ( $)$ : difference significant $p<0.05$; (*) difference significant $p<0.01$

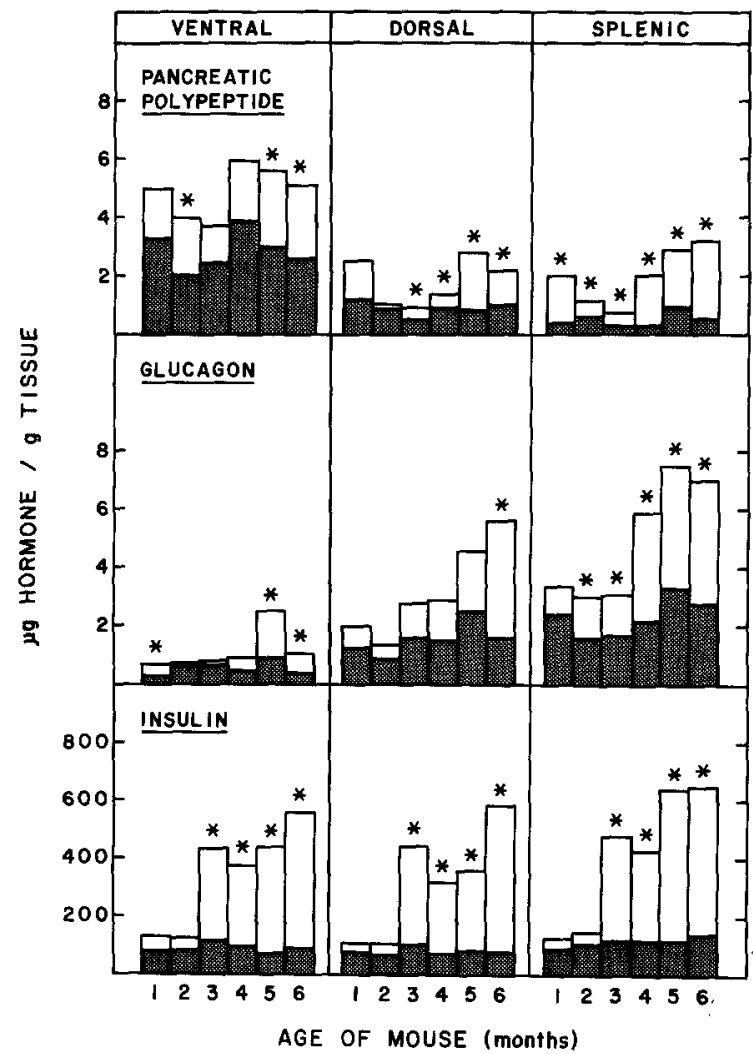

Fig. 6. Hormone content of individual pancreatic lobes. The data are the values for individual lobes from which the data in Figure 5 arose. Control ( $), \mathrm{ob} / \mathrm{ob}(\square) .{ }^{*} p<0.01$ for significant difference between lean and obese mice of the same age

ter reagent in order to obtain sufficient binding by hexapeptide antibody. This is not surprising since oxidative iodination predominantly introduces one or two iodine atoms at the carboxyl-terminal tyrosinamide [28]. Bulky iodine atoms at this position might well interfere with antigen-antibody interaction directed toward that portion of the molecule. We have recently isolated rat PP and are currently attempting to raise high titre antibodies to this peptide.

The finding of increased amounts of insulin in pancreatic extracts from ob/ob mice confirms findings of others [4-7,11], and the concentration of insulin in pancreas found by us, although a little lower, is in general agreement with these earlier reports. The same considerations hold for glucagon $[4,11]$, but our data show that the increased glucagon content is predominantly in the splenic lobe and preliminary cell counts indicate no increase in number of A cells per islet, a finding which indicates that the changes represent primarily A cell hypertrophy.

In the case of PP, there is not only increased PP content but also increased numbers of PP cells, as shown by Gingerich et al. [18]. We have preliminary data which show that this increase involves the dorsal and splenic lobes where PP cells normally are few in number and indicates not only hypertrophy but also hyperplasia of PP cells. The PP content of pancreatic extracts, according to our measurements, is considerably higher than the content reported by Gingerich et al. [18], but this is undoubtedly due to the different antiserum used by them (anti-bovine PP). Based on the dilution curve shown in Figure 3, our values probably give a reasonably accurate value for the PP content of murine pancreas.

The somatostatin content of mouse pancreatic extracts in this study (Fig. 5) is expressed in terms of $\mu \mathrm{g} / \mathrm{g}$ wet weight of tissue and is in reasonable agreement with the values for rat pancreatic extracts reported by Arimura et al. [30]. Patel et al. [8] reported somatostatin content of pancreas of mice to be $1.5 \mathrm{pg} / \mu \mathrm{g}$ protein and if one assumes protein content of the tissue to be $20 \%$, then this somatostatin content is equivalent to $0.3 \mu \mathrm{g} / \mathrm{g}$ wet weight, a value in the range of those in this study. Similar considerations hold for the data of Dolais-Kitabgi et al. [11], although we did not observe significant increases in pancreatic somatostatin in obese animals. The data for ob/ob mice $[7,8]$ are given in terms of islet content and are, therefore, difficult to relate to our data.

Since previous reports point to an association between some forms of obesity and PP deficiency, it is interesting that the PP content of pancreas of ob/ob mice is elevated compared with lean controls. This finding certainly suggests a defect in the secretory mechanism, the study of which in obese mice awaits the development of a high-titre specific antibody which will permit the study of PP secretion.
Acknowledgements. This work was supported by grants from the National Institute of Arthritis, Diabetes, Digestive and Kidney Diseases (No. AM-26191), the American Diabetes Association and Eli Lilly. The authors wish to thank B.E. Kimmel for his excellent technical assistance and G. Gillespie for her careful typing of the manuscript. 


\section{References}

1. Bray GA, York DA (1979) Hypothalamic and genetic obesity in experimental animals: an autonomic and endocrine hypothesis. Physiol Rev 59: 719-809

2. Gepts W, Christophe J, Mayer J (1960) Pancreatic islets in mice with the obese-hyperglycemic syndrome. Diabetes 9:63-69

3. Hellman B, Brolin S, Hellerstrom C, Hellman K (1961) The distribution pattern of the pancreatic islet cell volume in normal and hyperglycemic mice. Acta Endocrinol. 36: 609-616

4. Findlay JA, Rookledge KA, Beloff-Chain A, Lever JD (1973) A combined biochemical and histological study on the islets of Langerhans in the genetically obese hyperglycaemic mouse and in the lean mouse, including observations on the effects of streptozotocin treatment. J Endocrinol 56: 571-583

5. Stauffacher W, Lambert AE, Vecchio D, Renold AE (1967) Measurements of insulin activities in pancreas and serum of mice with spontaneous ("obese" and "New Zealand obese") and induced (gold thioglucose) obesity and hyperglycaemia, with considerations on the pathogenesis of the spontaneous syndrome. Diabetologia 3: $230-237$

6. Malaisse WJ, Malaisse-Lagae F, Coleman DL (1968) Insulin secretion in experimental obesity. Metabolism 17: 802-807

7. Genuth SM (1969) Hyperinsulinemia in mice with genetically determined obesity. Endocrinol 84: 386-391

8. Patel YC, Cameron DP, Stefan Y, Malaisse-Lagae F, Orci L (1977) Somatostatin: widespread abnormality in tissues of spontaneously diabetic mice. Science 198:930-931

9. Petersson B, Lundqvist G, Andersson A (1979) Somatostatin content and release from pancreatic islets from obese-hyperglycemic mice. Experentia 35: 127-128

10. Makino H, Matsushima Y, Kanatsuka A, Yamamoto M, Kumagai A, Nishimura M (1979) Changes in pancreatic somatostatin content in spontaneously diabetic mice, as determined by radioimmunoassay and immunohistochemical methods. Endocrinology 104: 243-247

11. Dolais-Kitabgi J, Le Marchand-Brustel Y, Freychet P (1979) Somatostatin in the pancreas and hypothalamus of obese mice. Diabetologia 17: $257-261$

12. Malaisse-Lagae F, Carpentier J-L, Patel YC, Malaisse WJ, Orci L (1977) Pancreatic polypeptide: a possible role in the regulation of food intake. Experientia 33:915-917

13. Baetens D, Stefan Y, Ravazzola M, Malaisse-Lagae F, Coleman DL, Orci L (1978) Alteration of islet cell populations in spontaneously diabetic mice. Diabetes $27: 1-7$

14. Strautz RL (1970) Studies of hereditary obese mice (ob/ob) after implantation of pancreatic islets in millipore filter capsules. Diabetologia $6: 306-312$

15. Gates RJ, Hunt MI, Smith R, Lazarus NR (1972) Return to normal of blood glucose, plasma insulin, and weight gain in New Zealand obese mice after implantation of islets of Langerhans. Lancet: $567-570$

16. Gates RJ, Hunt MI, Lazarus NR (1974) Further studies on the amelioration of the characteristics of New Zealand obese (NZO) mice following implantation of islets of Langerhans. Diabetologia 10: 401-406

17. Gates RJ, Lazarus NR (1977) The ability of pancreatic polypeptide (APP and BPP) to return to normal the hyperglycemia, hyperinsulinemia and weight gain of New Zealand obese mice. Hormone Res 8: 189-202

18. Gingerich RL, Gersell DJ, Greider MH, Finke EH, Lacy PE (1978) Elevated levels of pancreatic polypeptide in obese hyperglycemic mice. Metabolism 27: 1526-1532

19. Mordes JP, Eastwood GL, Loo S, Rossini AA (1982) Pancreatic polypeptide causes diarrhea and weight loss in obese mice but not in lean littermates. Peptides 3: 873-875

20. Marco J, Zulueta MA, Correas I, Villaneuva ML (1980) Reduced pancreatic polypeptide secretion in obese subjects. Endocrinology 50: 744-747

21. Lassmann V, Vague P, Vialettes B, Simon MC (1980) Low plasma levels of pancreatic polypeptide in obesity. Diabetes $29: 428-430$

22. Ziff G, O'Dorisio M, Cataland S, Dixon K (1983) Pancreatic polypeptide responses to protein meal challenges in obese but otherwise normal children and obese children with Prader-Willi syndrome. J Clin Endocrinol Metab 57: 1074-1080

23. Kimmel JR, Hayden LJ, Pollock HG (1975) Isolation and characterization of a new pancreatic polypeptide hormone. J Biol Chem 250: $9369-9376$

24. Baetens D, Malaisse-Lagae F, Perrelet A, Orci L (1979) Endocrine pancreas: three-dimensional reconstruction shows two types of islets of Langerhans. Science 206: 1323-1325

25. Morgan CR, Lazarow A (1963) Immunoassay of insulin: two antibody system. Diabetes 12:115-126

26. Tomita T (1980) Effect of alloxan on insulin and glucagon secretion in perifused islets. Diabetologia 19: 154-157

27. Lindall AW (1979) Somatostatin by radioimmunoassay. Immunonuclear Corporation Publications, Stillwater, MI, pp 20-21

28. Pollock HG, Kimmel JR (1981) Immunoassay for avian pancreatic polypeptide and applications in chickens. Gen Comp Endocrinol 45: 386-394

29. Bolton AE, Hunter WM (1973) The labelling of proteins to high specific radioactivities by conjugation to a ${ }^{125} \mathrm{I}$-containing acylating agent. Biochem J 133:529-538

30. Arimura A, Sato H, Dupont A, Nishi N, Schally AV (1981) Somatostatin: abundance of immunoreactive hormone in rat stomach and pancreas. Science 189: 1007-1009

Received: 24 August 1983

and in revised form: 9 August 1984

Dr. T. Tomita

Department of Pathology

University of Kansas College of

Health Sciences and Hospital

39th and Rainbow Boulevard

Kansas City, KS 66103

USA 